\title{
A Note on Corporate Capital Structure Theories
}

\section{Mawal Sara Saeed ${ }^{*}$}

\section{Introduction}

Financial theory revolves around rational participants who want to maximize their utility or wealth for a given level of risk. This maximization, in the first place, calls for the optimality of available resources, making capital financing decisions critical for corporations. Any discussion on optimal capital structure leads back to Modigliani and Miller's classical capital structure irrelevance hypothesis (1958), according to which, in an efficient market, the value of the firm is unaffected by its choice of capital structure in the absence of taxes, bankruptcy costs, and asymmetric information. This irrelevance makes the firm's managers indifferent to opting for debt or equity in the firm's capital structure.

Modigliani and Miller's proposition was criticized primarly for ignoring the tax shield that would be available if a firm was financed by debt. Later, Modigliani and Miller (1963) relaxed the assumption of zero taxes and demonstrated that debt financing might contribute toward the value of the firm, due to the available tax shield, but the impact was shown to be lower. Moreover, the use of debt financing leveraged the capital structure, consequently raising the cost of capital. The Modigliani and Miller propositions have had important implications for the theory of investment decisions. First, they demonstrate that such decisions can be separated from the corresponding financial decisions. Second, the rational criterion for investment decisions is a maximization of the market value of the firm. Last, the rational concept of capital cost refers to total cost, and should be measured as the rate of return on capital invested in shares of firms in the same risk class.

Building on the foundations of the Modigliani and Miller capital structure notion, an exhaustive body of literature on alternative theories of capital structure has emerged, debating the existence of an optimal capital structure and its impact on the cost of capital and, ultimately, on the value of the firm. These theories have been widely tested but contradictory empirical results raise questions about their validity. This note briefly discusses these theories of capital structure, along with some empirical findings.

\footnotetext{
* The author is a teaching associate at the Lahore School of Economics.
} 


\section{Static Tradeoff Theory}

Myers (1984) divides contemporary thinking on capital structure into two theoretical currents. The first is the static trade-off theory, which presumes that firms set up a debt target ratio and move toward it. According to this model, an optimal capital structure does exist and is found as the optimal tradeoff between the tax benefits of debt and the increase in the costs of financial distress associated with debt, i.e., bankruptcy costs against tax benefits.

\section{Pecking Order Theory}

Myers and Majluf (1984) posit that managers use private information to issue risky securities when they are overpriced. Investors are aware of this asymmetric information problem, and the prices of risky securities fall when new issues are announced. Managers anticipate the price declines and may forego profitable investment if they must be financed with risky securities. To avoid this distortion of investment decisions, managers follow what Myers (1984) calls the pecking order. They finance projects first with retained earnings, which have no asymmetric information problem; then with low-risk debt, for which the problem is negligible; and then with risky debt. Equity is issued only in distress or when investment exceeds earnings in a way that financing with debt would produce excessive leverage. Myers (1984) also suggests that, in the short term, dividends are (for unspecified reasons) sticky, leaving variations in net cash flows to be absorbed mainly by debt.

Furthermore, share repurchases give rise to asymmetric information problem. As Shyam-Sunder and Myers (1999) have pointed out, a firm that announces a repurchase will tempt investors to assume that managers have positive information not reflected in the stock price, causing the price to rise. This can deter the repurchase if the price rises above what managers consider to be the equilibrium level. Thus, when firms use financing retention to retire securities, they first retire debt. They retire equity only when leverage is low or when poor investment opportunities (relative to earnings) lower the value of debt capacity. In short, repurchases should be limited to firms with little or no leverage, few investment opportunities, or both.

Two additional points about the pecking order are pertinent when interpreting their empirical results. First, Myers (1984) emphasizes asymmetric information problems, but recognizes that transaction costs 
alone can produce pecking order financing if they are higher for debt than for retained earnings and higher yet for equity. In other words, asymmetric information may be unnecessary. Transaction costs can give rise to a pecking order.

Second, in Myers (1984) and Myers and Majluf (1984), the pecking order arises through an implicit assumption that there is no way to issue equity that avoids asymmetric information problems. If firms find ways to issue equity without such problems, asymmetric information might not constrain equity issues. As a result, pecking order financing can disappear, i.e., financing with equity is not a last resort, the incentive to avoid repurchases to maintain debt capacity is gone, and asymmetric information problems do not drive capital structures. This does not mean that asymmetric information is irrelevant, but its implications do become quite limited. Firms avoid issuing risky securities in ways that involve asymmetric information problems, but financing decisions do not follow the pecking order.

\section{Market Timing Hypothesis}

Equity market timing refers to the practice of issuing equities at high prices and repurchasing them at low prices to exploit temporary fluctuations in the cost of equity relative to the cost of other fund-raising measures. In the efficient and integrated capital markets assumed by the Modigliani and Miller theorem, the costs of different forms of capital do not vary independently and thus no gain can be obtained from opportunistically switching between debt and equity.

Also, according to the tradeoff theory, when equity prices rise, the market value of leverage ratios fall and firms try to raise leverage ratios by increasing debt and/or repurchasing equity. Thus, the market timing hypothesis predicts the opposite direction envisaged by the tradeoff theory. In practice, many market participants point out that firms tend to issue equities instead of debts when market value is high, relative to book value and past market values, and tend to repurchase them when market value is low.

\section{Agency Theory and Capital Structure}

There are three kinds of agency costs that bring in the importance of capital structure when calculating the worth of a firm. The first factor is the asset substitution effect, which states that, with increased levels of leverage, the management is induced to take up even those projects with a 
negative net present value (NPV). If the project becomes successful, then shareholders are entitled ownership of all the gains and debt holders receive their pre-fixed rate of return, whereas unsuccessful ventures result in debt holders also sharing the loss. This could result in a transfer of wealth from debt holders to shareholders.

Another problem is that of underinvestment. In situations where debt is risky, the gains are passed on to the debt holders for taking that risk. This results in the rejection of such projects that would yield positive future cash flows and have a positive NPV, and would also result in an increase in the value of the firm.

There is a significant body of literature that models the influence of agency costs on capital structure stemming from conflicts of interest. Jensen and Meckling (1976) argue that a conflict of interest can arise between shareholders and managers since the latter hold less than 100 percent of the residual claims. Consequently, they do not capture the entire gain from their profit-enhancing activities, but instead bear the entire cost of these activities. For instance, managers can invest less effort in managing firm resources and may be able to transfer firm resources for their personal benefit by consuming "perquisites". This inefficiency is reduced as the fraction of the firm's equity owned by managers' increases-the larger the shareholding ratio of large investors, the more effective their monitoring. This leads to less chance of conflicts of interest.

Another conflict could be posed by the availability of free cash flows. If the management's tendency is that of an empire builder, it will undertake high-risk projects-the underlying risk of which will be borne by the shareholders. Therefore, increases in debt levels for firms with positive free cash flows will reduce the agency problem because it will force the management to pay out the excess cash. Thus debt acts as a monitor of firm performance, it requires management to run the firm efficiently to avoid the negative consequences of not being able to service the firm's debt payments, and it requires the management to disburse its free cash flow.

\section{Some Empirical Evidence on Capital Structure Theories}

As mentioned earlier, the alternative theories of capital structure along with Modigliani and Miller's basic irrelevance theorem has been widely discussed in the financial literature. No single theory explains all the time-series and cross-sectional patterns that have been documented. The relative importance of these explanations has varied in different studies. Shyam-Sunder and Myers (1999) test the pecking order theory by 
estimating a regression using a firm's net debt issuance as the dependent variable and its net financing deficit as the independent variable. They find that the estimated coefficient on the financing deficit is close to 1 for their sample and interpret the evidence as supporting the pecking order theory.

In general, the pecking order theory enjoyed increasing favor in the 1990s, but has recently fallen on hard times. Chirinko and Singha (2000) use three examples to illustrate potential problems with using the ShyamSunder and Myers test to evaluate the theory. Frank and Goyal (2003) argue that none of its predictions hold when a broad sample of firms and a longer time-series is used. Fama and French (2002) find that short-term variations in earnings and investment are mostly absorbed by debt, as predicted by the pecking order, but that it has other failings (namely significant equity issues by small-growth firms). Baker and Wurgler (2002) relate capital structure to historical market-to-book ratios. With their findings, the market timing theory has increasingly challenged both the static tradeoff and pecking order theories.

Fama and French (2004) reject the pecking order theory's central predictions about how often and under what circumstances firms issue and repurchase equity. First, they report that equity issues were commonplace during 1973-2002, and so pervasive that they could not have been limited to firms in distress. Second, repurchases have turned out to be not that rare. Further, they attribute the failure of pecking order breaks at least in part to equity issue with low transaction costs and modest asymmetric information problems. Three of the alternatives to traditional equity offering include issues to employees, rights issues, and direct purchase plans, which have both low transaction costs and minor asymmetric information problems. A fourth, mergers financed by stock, could also fall into this category. They argue that, if there are ways to issue equity that avoids the costs assumed by the pecking order theory, transaction costs and asymmetric information problems might not seriously constrain equity issuance. Therefore, equity issuance is not the last option for raising finance and the asymmetric information problem that is the focus of the pecking order theory is not the sole or perhaps even an important determinant of capital structure.

Fama and French (2004) disagree with Shyam-Sunder and Myers (1999) about the success of the pecking order model, but agree with their conclusion that its main competitor, the tradeoff model, has serious problems. Like asymmetric information, tradeoff considerations (for example, the bankruptcy cost of debt) surely plays a role in financing decisions. However, there are important aspects of the tradeoff model that get little empirical support. They conclude that the tradeoff model and 
pecking order model have serious problems, challenging their position as stand-alone theories of capital structure. Perhaps it is best to regard the two models as "stablemates, each with elements of truth that help explain some aspects of financing decisions."

Ismail and Eldomiaty (2004) compare the three capital structure theories using the stochastic search variable selection procedure. They observe that, with innovations in economic and business dynamics, no single theory can explain capital structure choice. Their results support the pecking order and static tradeoff propositions while they cannot deduce any significance for the agency and free cash flow theories. They attribute the transition of manager choices from the pecking order to tradeoff theories and vice versa to factors such as market and financial risk, tax shield, firm growth rate, and expected investment opportunities.

Dittmar and Thakor (2007) present an alternative theory of capital structure and provide supporting empirical evidence. They find little or no evidence for other known theories such as the pecking order, static tradeoff, timing, and time-varying adverse selection theories. Although the agreement theory appears to be an extension of the timing and time-varying adverse selection theories, there is a major difference. In the timing theory, high stock prices are a consequence of overvaluation while in the agreement model they are the result of market agreement. In the time-varying adverse selection theory, they are attributed to low information asymmetry. Apart from this, the authors claim that, given the model and the empirical evidence, their theory has incremental explanatory power over the timing and time-varying adverse selection hypotheses concerning security issuance decisions. The model's variables provide insight into the firm's capital structure and investment decisions, and the statistics demonstrate that manager-investor agreement is a determinant of corporate decisions.

\section{Conclusion}

Capital structure choice is one of the critical decisions that a firm's management must make. The empirical literature on the subject is exhaustive, and focuses on the various determinants that drive this choice. However, the empirical findings are not conclusive since the results support and fail to support the capital structure theories that have been proposed over the last 50 years. Even five decades after Modigliani and Miller's seminal paper, capital structure choice is still largely a puzzle and warrants further research on the option of debt versus equity in a dynamic business and economic environment. 


\section{References}

Baker, M., \& Wurgler, J. (2002). Market timing and capital structure. Journal of Finance, 57, 1-32.

Chirinko, R., \& Singha, A. (2000). Testing static tradeoff against pecking order models of capital atructure: A critical comment. Journal of Financial Economics, 58, 417-425.

Dittmar, A., \& Thakor, A. (2007). Why do firms issue equity? Journal of Finance, 72, 1-54.

Fama, E. F., \& French, K. R. (2002). Testing tradeoff and pecking order predictions about dividends and debt. Review of Financial Studies, 15, 1-33.

Fama, E. F., \& French, K. R. (2004). Financing decisions: Who issues stock? Journal of Financial Economics, 76, 549-582.

Frank, M., \& Goyal, V. (2003). Testing the pecking order theory of capital structure. Journal of Financial Economics, 67, 217-248.

Jensen, M. C., \& Meckling, W. (1976). Theory of the firm: Managerial behavior, agency costs, and ownership structure. Journal of Financial Economics, 3(4), 305-360.

Ismail, A. M., \& Eldomiaty, I. T. (2004). Bayesian identification of the predictors for capital structure in Egypt. Advances and Applications in Statistics, 4(2), 15-35.

Modigliani, F., \& Miller, M. H. (1958). The cost of capital, corporation investment, and the theory of investment. American Economic Review, 48, 261-297.

Modigliani, F., \& Miller, M. H. (1963). Corporate income taxes and the cost of capital: A correction. American Economic Review, 53(3), 433443.

Myers, S. C. (1984). The capital structure puzzle. Journal of Finance, 39, 575-592. 
Myers, S. C., \& Majluf, N. (1984). Corporate finance and investment decisions when firms have information that investors do not have. Journal of Financial Economics, 13, 187-221.

Shyam-Sunder, L., \& Myers, S. (1999). Testing static tradeoff against pecking order models of capital structure. Journal of Financial Economics, 51, 219-244. 